\title{
PERTUMBUHAN, UMUR, DAN DIMORFISME SEKSUAL IKAN PELANGI ARFAK, Melanotaenia arfakensis Allen, 1990 DI SISTEM SUNGAI PRAFI, MANOKWARI, PAPUA BARAT
}

\section{Growth, Age, and Sexual Dimorphism of the Arfak Rainbowfish, Melanotaenia arfakensis Allen, 1990 at Prafi River System, Manokwari, West Papua}

\author{
Emmanuel Manangkalangi ${ }^{1,5}$, Simon P.O. Leatemia ${ }^{1}$, Luky Sembel ${ }^{2}$, Paskalina T. Lefaan ${ }^{3}$, \\ Ridwan $\mathrm{Sala}^{2}$, M.F. Rahardjo ${ }^{4,5}$ \\ ${ }^{1}$ Jurusan Perikanan, Fakultas Perikanan dan Ilmu Kelautan UNIPA, Manokwari 98314 \\ ${ }^{2}$ Jurusan Ilmu Kelautan, Fakultas Perikanan dan Ilmu Kelautan UNIPA, Manokwari \\ ${ }^{3}$ Jurusan Biologi, Fakultas Matematika dan IPA, UNIPA, Manokwari \\ ${ }^{4}$ Departemen Manajemen Sumberdaya Perairan, FPIK-IPB, Bogor \\ ${ }^{5}$ Masyarakat Iktiologi Indonesia
}

*Korespondensi: e_manangkalangi2013@yahoo.com

\begin{abstract}
Arfak rainbow fish, Melanotaenia arfakensis is an endemic fish on several river systems in the northeastern part of the Vogelkop peninsula. This study aims to describe the growth, age at first maturity, and sexual dimorphism of this endemic fish on the Nimbai Stream and the Aimasi Stream, the Prafi River system. The fish were caught using handnet, then were measured their standard length and individual weight. Data were analyzed to estimated growth patterns, von Bertalanffy's growth rate, age at first maturity and sexual dimorphism characteristics. The results showed that male growth patterns varied, with a tendency of the increase in body length faster than that of body weight (negative allometric patterns) with $b$ values ranging from 2.886 to 3.132. On the other hand, the female individuals had positive allometric patterns ( $b$ values ranged from 3.062 to 3.378$)$. The growth rate $(\mathrm{K})$ of male body length was faster $(0.165-0.174)$ than that of female individuals (0.159-0.163). Male individuals reached the first maturity condition earlier (at age of 1.83-2.18 years) than female individuals (at age of 2.49-2.64 years). Sexual characteristics between the sexes are related to body height starting to appear when fish are of a standard length of larger than $18.22 \mathrm{~mm}$ or when male fish begin to approach the time of the first sexual maturity. Understanding of growth, age, and the characteristics of the sexual dimorphism of endemic fish has an important meaning in monitoring population conditions and for conservation efforts in their natural habitat.
\end{abstract}

\begin{abstract}
ABSTRAK
Ikan pelangi arfak, Melanotaenia arfakensis merupakan ikan endemik pada beberapa sistem sungai di bagian timur laut semenanjung Vogelkop. Penelitian ini bertujuan untuk mendeskripsikan pertumbuhan, umur kali pertama matang kelamin, dan dismorfisme seksual ikan endemik ini di Sungai Nimbai dan Sungai Aimasi, sistem Sungai Prafi. Ikan ditangkap menggunakan handnet lalu diukur panjang baku dan berat per individu. Analisis yang digunakan, yaitu pola pertumbuhan, pertumbuhan dengan persamaan von Bertalanffy, umur kali pertama matang kelamin, dan karakter dimorfisme seksual. Hasil penelitian menunjukkan bahwa pola pertumbuhan individu jantan bervariasi, dengan kecenderung pertambahan panjang tubuh lebih cepat dibandingkan berat tubuhnya (pola alometrik negatif) dengan nilai b berkisar 2.886-3.132, sedangkan individu betina memiliki pola alometrik positif (nilai b berkisar 3.062-3.378). Laju pertumbuhan (K) panjang tubuh individu jantan lebih cepat (0.165-0.174) dibandingkan individu betina (0.159-0.163). Individu jantan mencapai kondisi kali pertama matang kelamin pada umur yang lebih muda (1.83-2.18 tahun) dan individu betina (2.49-2.64 tahun). Karakteristik seksual di antara kedua jenis kelamin berkaitan dengan tinggi tubuh mulai terlihat ketika ikan berukuran panjang baku $>18.22 \mathrm{~mm}$ atau ketika ikan jantan mulai mendekati waktu kali pertama matang kelamin. Pemahaman mengenai pertumbuhan, umur, dan karakteristik dimorfisme seksual ikan endemik ini memiliki arti penting dalam pemantauan kondisi populasi yang berimplikasi terhadap upaya pelestarian di habitat alaminya.
\end{abstract}

Keywords: age, growth, rainbow fish, sexual dimorphism, sexual maturity 


\section{PENDAHULUAN}

Pertumbuhan adalah salah satu komponen yang penting dalam proses siklus hidup organisme, termasuk kelompok ikan. Ada banyak faktor intrinsik dan ekstrinsik yang memengaruhi pertumbuhan, yaitu konsumsi, metabolisme, reproduksi dan lingkungan yang akan saling berinteraksi sampai batas tertentu (van Poorten \& Walters, 2016). Dua parameter yang secara umum digunakan untuk mengekspresikan pertumbuhan, yaitu panjang dan berat tubuh. Berdasarkan kedua parameter ini, pertumbuhan pada ikan bisa diestimasi, misalnya melalui hubungan panjang-berat (Okgerman, 2005) dan persamaan pertumbuhan von Bertalanffy (Essington et al., 2001). Hubungan panjang-berat dan pertumbuhan akan bervariasi di antara tahap perkembangan (umur) dan jenis kelamin (Lloret \& Planes, 2003), juga terkait dengan kondisi metabolisme dan lingkungan hidup setiap spesies ikan (Gonzalez-Ganadara et al., 2003). Oleh karena itu, nilai yang diperoleh dari pendekatan ini dapat menggambarkan laju pertumbuhan dan kondisi ikan secara spasial ataupun temporal (Meretsky et al., 2000, Stevenson \& Woods 2006). Sebagai contoh, pendekatan ini secara spasial dapat menggambarkan kesesuaian habitat bagi suatu tahap perkembangan ikan (Ribeiro et al., 2004) dan secara temporal menunjukkan status reproduksinya (Lloret \& Planes, 2003; Manangkalangi et al., 2009b). Oleh karena itu, berbagai informasi ini memiliki implikasi penting dalam pemantauan status dan pemulihan populasi ikan di habitat alami untuk memastikan upaya pelestariannya yang lebih baik (Lambert \& Dutil, 1997, Meretsky et al., 2000).

Ikan pelangi arfak, Melanotaenia arfakensis adalah salah satu jenis fauna ikan yang endemis pada beberapa sungai di bagian timur laut Vogelkop (Kepala Burung). Persebaran ikan ini mulai dari daerah Prafi di bagian timur (Allen 1990, Manangkalangi et al. 2009a, 2014) sampai Kebar di bagian barat (Manangkalangi \& Pattiasina, 2005, Kadarusman et al., 2012). Selain daerah persebaran terbatas, status ikan ini sudah termasuk dalam kategori rawan punah (vulnerable) dengan kecenderungan populasi di habitat alami yang belum diketahui (IUCN 2018). Namun diduga kondisi populasinya semakin menurun berkaitan dengan degradasi kualitas habitat alaminya. Degradasi habitat alami berkaitan dengan konversi hutan menjadi perkebunan kelapa sawit dan pertanian, serta pemukiman transmigrasi (Polhemus et al. 2004), dan juga terkait dengan masuknya limbah pengolahan minyak kelapa sawit dan ikan asing ke dalam sistem Sungai Nimbai, Prafi (Manangkalangi et al. 2014). Oleh karena itu diperlukan beberapa informasi, di antaranya pertumbuhan dan ukuran kali pertama matang kelamin sebagai acuan dalam pemantauan tren populasi ikan endemis ini di habitat alaminya. Namun demikian, kedua informasi ini masih terbatas hanya berdasarkan hasil penelitian Manangkalangi \& Pattiasina (2005) dari perairan tawar di Kebar (wilayah barat persebarannya), sedangkan di sistem Sungai Prafi (wilayah timur persebarannya) belum pernah dilakukan. Oleh karena itu, penelitian ini dilakukan dengan tujuan untuk mendeskripsikan pertumbuhan, umur kali pertama matang kelamin dan karakteristik dimorfisme seksual pada ikan pelangi arfak di Sungai Nimbai dan Sungai Aimasi, sistem Sungai Prafi.

\section{METODE}

Penelitian ini dilakukan di dua sungai dalam sistem Sungai Prafi, yaitu Sungai Nimbai dan Sungai Aimasi (Tabel 1). Pengambilan contoh ikan pelangi arfak dilakukan setiap bulan dalam periode tujuh bulan (Juni-Desember). Dengan mempertimbangkan karakteristik spesies ikan ini yang berkaitan dengan adanya habitat ontogenetik (Manangkalangi et al., 2009a), maka pengumpulan contoh dilakukan pada empat tipe habitat. Keempat tipe habitat ini meliputi daerah lubuk (LBK), daerah beraliran deras (DAD), tepi sungai beraliran sedang (TAS) dan tepi beraliran lambat (TAL).

Penangkapan contoh ikan pada setiap tipe habitat dilakukan dengan menggunakan alat hand net (panjang $3 \mathrm{~m}$, tinggi $2 \mathrm{~m}$ dan ukuran mata jaring $1 \mathrm{~mm}$ ). Contoh ikan yang telah dikoleksi 
Tabel 1. Posisi geografis dan ketinggian setiap tipe habitat di lokasi penelitian. $\mathrm{m}$ dpl adalah meter di atas permukaan laut.

\begin{tabular}{lcccc}
\hline \multicolumn{1}{c}{ Lokasi } & $\begin{array}{c}\text { Tipe } \\
\text { Habitat }\end{array}$ & $\begin{array}{c}\text { Lintang } \\
\text { Selatan }\end{array}$ & $\begin{array}{c}\text { Bujur } \\
\text { Timur }\end{array}$ & $\begin{array}{c}\text { Ketinggian } \\
(\mathrm{m} \mathrm{dpl})\end{array}$ \\
\hline \multirow{3}{*}{ Sungai } & TAL & $0056^{\prime} 01,8^{\prime \prime}$ & $13351^{\prime} 52,8^{\prime \prime}$ & 117 \\
Nimbai & TAS & $0056^{\prime} 02,3^{\prime \prime}$ & $13351^{\prime} 51,7^{\prime \prime}$ & 117 \\
& LBK & $0055^{\prime} 55,0^{\prime \prime}$ & $13351^{\prime} 49,7^{\prime \prime}$ & 115 \\
& DAD & $0056^{\prime} 05,4^{\prime \prime}$ & $13351^{\prime} 53,2^{\prime \prime}$ & 117 \\
\hline \multirow{3}{*}{ Sungai } & TAL & $0055^{\prime} 17,0^{\prime \prime}$ & $13348^{\prime} 28,3^{\prime \prime}$ & 133 \\
Aimasi & TAS & $0055^{\prime} 17,5^{\prime \prime}$ & $13348 ' 28,4^{\prime \prime}$ & 134 \\
& LBK & $0055^{\prime} 17,6^{\prime \prime}$ & $1334828,4^{\prime \prime}$ & 134 \\
& DAD & $0055^{\prime} 16,0^{\prime \prime}$ & $13348 ' 26,1^{\prime \prime}$ & 131 \\
\hline
\end{tabular}

berdasarkan lokasi dan tipe habitat selanjutnya diawetkan dengan larutan formalin $4 \%$ dan dibawa ke Laboratorium Perikanan, Fakultas Perikanan dan Ilmu Kelautan UNIPA. Setiap contoh ikan dilakukan penimbangan berat tubuh dengan menggunakan timbangan berketelitian 0.001 gram dan pengukuran karakter morfometrik (yaitu panjang baku dan tinggi tubuh) dengan menggunakan kaliper digital berketelitian $0.01 \mathrm{~mm}$. Contoh ikan dibedah dan diidentifikasi jenis kelamin serta tingkat kematangan gonadnya secara morfologis dengan mengacu pada Manangkalangi et al., (2009b).

\section{Analisis Data}

\section{Hubungan Panjang-Berat dengan Pola} Pertumbuhan

Analisis hubungan panjang berat (HPB) dilakukan menggunakan rumus $\mathrm{W}=\mathrm{aL}^{\mathrm{b}}$, dengan W sebagai berat tubuh (gram), L sebagai panjang baku (mm), a dan b adalah konstanta regresi (Le Cren 1951). Untuk menentukan pola pertumbuhan, maka uji t $(\mathrm{p}<0,05)$ digunakan untuk menguji nilai $b$ terhadap nilai 3 . Jika nilai $\mathrm{b}=3$ berarti ikan memiliki pola pertumbuhan isometrik, dan sebaliknya bila $b \neq 3$ berarti pola pertumbuhan bersifat alometrik. Untuk pola pertumbuhan alometrik berkisar di antara alometrik negatif $(b<3)$ dan alometrik positif $(b$ $>3$ ).

\section{Pertumbuhan}

Untuk penentuan kelompok umur (kohort) digunakan analisis distribusi frekuensi panjang yang dilanjutkan dengan pemisahannya menggunakan metode Bhattacharya dalam program FiSAT II (ver 1.1.3). Pertumbuhan diduga menggunakan persamaan von Bertalanffy (Sparre \& Venema, 1998), yaitu $\mathrm{L}_{\mathrm{t}}=\mathrm{L}_{\infty}\left(1-\mathrm{e}^{-\mathrm{K}\left(\mathrm{t}-\mathrm{t}_{0}\right)}\right), \quad$ dengan $\mathrm{L}_{\mathrm{t}}=$ panjang waktu ke-t, $\mathrm{L}_{\infty}=$ panjang infiniti, $\mathrm{K}=$ koefisien pertumbuhan, dan $\mathrm{t}_{0}=$ umur teoritis saat panjang ikan sama dengan 0 .

\section{Ukuran Kali Pertama Matang Kelamin}

Pendugaan ukuran kali pertama matang kelamin ditentukan menggunakan metode Spearman-Karber (Udupa 1986), yaitu $m=X_{k}+$ $(\mathrm{X} / 2)-\left(\mathrm{X} \Sigma \mathrm{p}_{\mathrm{i}}\right)$, dengan $\mathrm{m}=$ logaritma panjang ikan saat pertama kali matang gonad, $X_{k}=$ logaritma nilai tengah kelas panjang yang terdapat $100 \%$ ikan matang gonad, $\mathrm{X}=$ selisih logaritma nilai tengah kelas, $\mathrm{X}_{\mathrm{i}}=$ logaritma nilai tengah kelas ke-i, $p_{i}=$ proporsi dari ikan yang matang gonad dalam kelas panjang ke-i, $r_{i}=$ jumlah ikan matang gonad dalam kelas panjang ke-i, $n_{i}=$ jumlah ikan dalam kelas panjang ke-i, $p_{i}$ $=r_{i} / n_{i}, q_{i}=1-p_{i}$.

\section{Karakteristik Dimorfisme Seksual}

Penentuan karakteristik dimorfisme seksual dilakukan dengan memetakan proporsi tinggi tubuh terhadap panjang baku (TT/PB) dan panjang baku (PB) pada kedua jenis kelamin. Pemetaan ini dilakukan dengan menggunakan regresi linier: TT/PB $=a+b$ PB. TT/PB adalah proporsi ukuran tinggi tubuh terhadap panjang baku setiap inidividu, PB adalah ukuran panjang baku setiap individu, dan konstanta regresi $(a, b)$. 
HASIL DAN PEMBAHASAN

Hubungan Panjang Berat dan Pola Pertumbuhan

Persamaan hubungan panjang-berat tubuh ikan pelangi arfak yang diperoleh dalam penelitian ini ditampilkan pada Tabel 2 dan 3. Panjang dan berat memiliki korelasi yang kuat dan ditunjukkan dengan nilai r yang mendekati 1 . Nilai b yang mengekspresikan laju pertumbuhan menunjukan pola pertumbuhan yang bervariasi di antara kedua jenis kelamin. Individu jantan memiliki pola pertumbuhan yang bervariasi, namun cenderung alometrik negatif (penambahan panjang tubuh lebih cepat dari penambahan berat tubuh), sedangkan individu betina memiliki pola alometrik positif (penambahan panjang tubuh lebih lambat dari penambahan berat tubuh).
Pola alometrik negatif individu jantan menunjukkan energi yang diperoleh lebih banyak diinvestasikan untuk pertumbuhan panjang tubuh. Setelah jantan mencapai ukuran minimum reproduksi, maka tahap selanjutnya energi dialokasikan untuk pertumbuhan berat. Pola sebaliknya pada individu betina, sebelum permulaan reproduksi, energi akan diinvestasikan untuk peningkatan berat tubuh (alometrik positif), setelah proses reproduksi berlangsung maka berat tubuh akan berkurang melalui pemijahan. Selain variasi di antara jenis kelamin, perbedaan pertumbuhan ikan yang diekspresikan dari nilai $b$ dapat disebabkan oleh beberapa faktor, yaitu perbedaan umur, perkembangan gonad, kondisi habitat, kepenuhan lambung, faktor penyakit, dan parasit (Le Cren, 1951, Freitas et al., 2016).

Tabel 2. Hubungan panjang-berat dan pola pertumbuhan ikan pelangi arfak di Sungai Nimbai. *dilakukan uji t untuk menentukan apakah nilai b berbeda nyata atau tidak dari $3,{ }^{a}$ alometrik positif $(b<3),{ }^{b}$ isometrik $(b=3)$, ${ }^{c}$ alometrik negatif $(b>3)$.

\begin{tabular}{lcccccccc}
\hline \multirow{2}{*}{\multicolumn{1}{c}{ Bulan }} & \multicolumn{3}{c}{ Jantan } & \multicolumn{5}{c}{ Betina } \\
\cline { 2 - 9 } & $\mathrm{a}$ & $\mathrm{b}^{*}$ & $\mathrm{r}^{2}$ & $\mathrm{n}$ & $\mathrm{a}$ & $\mathrm{b}^{*}$ & $\mathrm{r}^{2}$ & $\mathrm{n}$ \\
\hline Juni & 0.000015 & $3.034^{\mathrm{a}}$ & 0.973 & 20 & 0.000006 & $3.317^{\mathrm{a}}$ & 0.961 & 17 \\
Juli & 0.000018 & $2.977^{\mathrm{c}}$ & 0.993 & 21 & 0.000010 & $3.188^{\mathrm{a}}$ & 0.979 & 26 \\
Agustus & 0.000012 & $3.134^{\mathrm{a}}$ & 0.966 & 28 & 0.000014 & $3.094^{\mathrm{a}}$ & 0.987 & 28 \\
September & 0.000017 & $2.993^{\mathrm{c}}$ & 0.992 & 35 & 0.000010 & $3.211^{\mathrm{a}}$ & 0.926 & 33 \\
Oktober & 0.000018 & $2.962^{\mathrm{c}}$ & 0.984 & 31 & 0.000016 & $3.062^{\mathrm{a}}$ & 0.992 & 23 \\
November & 0.000019 & $2.956^{\mathrm{b}}$ & 0.996 & 24 & 0.000009 & $3.227^{\mathrm{a}}$ & 0.978 & 31 \\
Desember & 0.000021 & $2.931^{\mathrm{c}}$ & 0.990 & 13 & 0.000009 & $3.172^{\mathrm{a}}$ & 0.945 & 11 \\
Keseluruhan & 0.000019 & $2.965^{\mathrm{c}}$ & 0.988 & 172 & 0.000012 & $3.131^{\mathrm{a}}$ & 0.974 & 169 \\
\hline
\end{tabular}

Tabel 3. Hubungan panjang-berat dan pola pertumbuhan ikan pelangi arfak di Sungai Aimasi. *dilakukan uji t untuk menentukan apakah nilai b berbeda nyata atau tidak dari $3,{ }^{a}$ alometrik positif $(b<3),{ }^{b}$ isometrik $(b=3),{ }^{c}$ alometrik negatif $(b>3)$.

\begin{tabular}{lcccccccc}
\hline \multirow{2}{*}{ Bulan } & \multicolumn{4}{c}{ Jantan } & \multicolumn{3}{c}{ Betina } \\
\cline { 2 - 9 } & $\mathrm{a}$ & $\mathrm{b}^{*}$ & $\mathrm{r}^{2}$ & $\mathrm{n}$ & $\mathrm{a}$ & $\mathrm{b}^{*}$ & $\mathrm{r}^{2}$ & $\mathrm{n}$ \\
\hline Juli & 0,000027 & $2,886^{\mathrm{c}}$ & 0,997 & 12 & 0,000016 & $3,077^{\mathrm{a}}$ & 0,979 & 17 \\
Agustus & 0,000017 & $2,992^{\mathrm{b}}$ & 0,996 & 24 & 0,000019 & $3,042^{\mathrm{a}}$ & 0,993 & 33 \\
September & 0,000015 & $3,042^{\mathrm{a}}$ & 0,991 & 36 & 0,000008 & $3,274^{\mathrm{a}}$ & 0,982 & 39 \\
Oktober & 0,000018 & $2,994^{\mathrm{b}}$ & 0,992 & 36 & 0,000012 & $3,132^{\mathrm{a}}$ & 0,983 & 35 \\
November & 0,000018 & $2,968^{\mathrm{c}}$ & 0,991 & 38 & 0,000005 & $3,378^{\mathrm{a}}$ & 0,986 & 43 \\
Desember & 0,000018 & $2,974^{\mathrm{c}}$ & 0,977 & 21 & 0,000007 & $3,305^{\mathrm{a}}$ & 0,989 & 22 \\
Keseluruhan & 0,000017 & $3,003^{\mathrm{a}}$ & 0,992 & 167 & 0,000013 & $3,130^{\mathrm{a}}$ & 0,981 & 189 \\
\hline
\end{tabular}




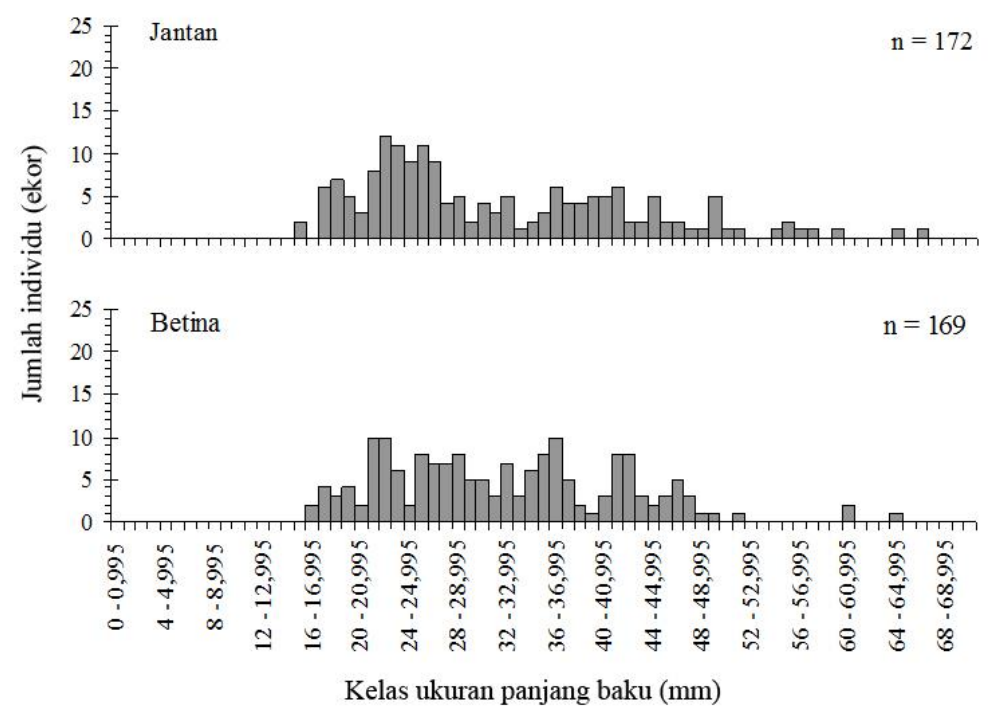

Gambar 1. Sebaran frekuensi panjang baku ikan pelangi arfak di S. Nimbai

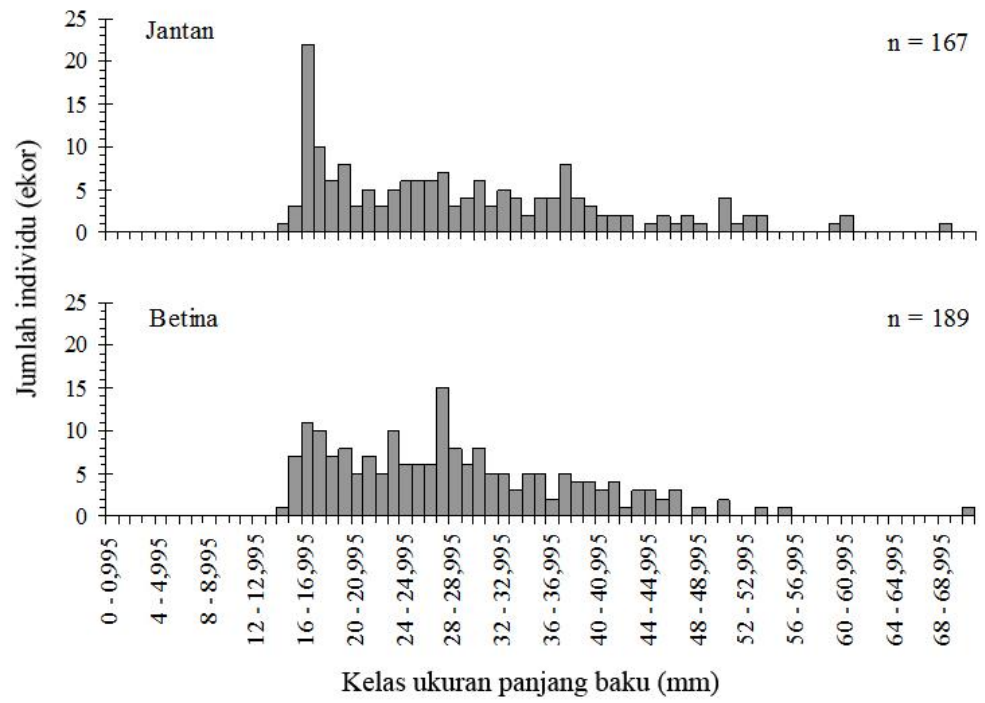

Gambar 2. Sebaran frekuensi panjang baku ikan pelangi arfak di S. Aimasi

\section{Pertumbuhan}

Sebaran frekuensi ukuran panjang baku ikan pelangi arfak berdasarkan jenis kelamin dan lokasi ditunjukkan pada Gambar 1 dan 2. Berdasarkan hasil pengelompokan ke dalam kelas ukuran panjang baku (PB) $1 \mathrm{~mm}$, diperoleh distribusi normal yang mewakili lima kelompok umur (Tabel 4). Keberhasilan pemisahan dua komponen yang berdekatan dalam penentuan kelompok umur dengan metode Bhattacharya harus memperhatikan nilai indeks pemisah (IP) (Sparre \& Venema, 1998). Nilai indeks ini harus sama dengan atau lebih besar dari nilai dua (Gayanilo et al., 1996).
Bentuk persamaan pertumbuhan $M$. arfakensis berdasarkan jenis kelamin dan lokasi penelitian ditunjukkan pada Gambar 3. Individu jantan bertumbuh lebih cepat dan mencapai ukuran yang lebih besar, kecuali di lokasi Sungai Aimasi yang ditemukan individu betina berukuran lebih besar $(70.27 \mathrm{~mm})$. Laju pertumbuhan yang lebih cepat pada individu jantan ditandai dengan koefisien pertumbuhan (K) yang lebih besar di kedua lokasi penelitian. Hal ini berkaitan dengan alokasi energi individu jantan yang relatif lebih besar pada pertumbuhan jaringan somatik dibandingkan jaringan reproduksinya (Milton \& Arthington, 1984). 
Selanjutnya cadangan energi somatik yang dihasilkan dalam proses pertumbuhan akan digunakan untuk perkembangan karakter seksual primer dan sekunder (Jonsson \& Jonsson, 2011) sehingga ada hubungan dengan ukuran dan umur saat matang kelamin (Plaistow et al., 2004). Pertumbuhan lebih cepat akan meningkatkan keuntungan berkompetisi dengan individu jantan yang lain terhadap akses ke individu betina untuk reproduksi (Freitas et al., 2016).
Jika dibandingkan dengan hasil penelitian sebelumnya di perairan Kebar (Manangkalangi \&Pattiasina, 2005), maka koefisien pertumbuhan pada kedua lokasi di sistem Sungai Prafi ini relatif lebih kecil. Kondisi ini diduga berkaitan dengan kualitas lingkungan yang relatif lebih baik pada beberapa sungai di daerah Kebar, dan juga hal ini terlihat dari ukuran maksimal yang diperoleh dalam penelitian tersebut $(\mathrm{PB}=74,95$ $\mathrm{mm})$.

Tabel 4. Modus PB dari kelompok umur $\left(\mathrm{L}_{\mathrm{t}}\right)$ ikan pelangi arfak di S. Nimbai dan S. Aimasi yang diperoleh dengan program FiSAT II. IP = indeks pemisah.

\begin{tabular}{cccccc}
\hline \multirow{2}{*}{$\begin{array}{c}\text { Jenis } \\
\text { Kelamin }\end{array}$} & Kelompok & \multicolumn{2}{c}{ Sungai Nimbai } & \multicolumn{2}{c}{ Sungai Aimasi } \\
\cline { 3 - 6 } & Umur & Modus PB $\left(\mathrm{L}_{\mathrm{t}}\right)$ & IP & Modus PB $\left(\mathrm{L}_{\mathrm{t}}\right)$ & IP \\
\hline Jantan & 1 & 18,31 & - & 17,92 & - \\
& 2 & 24,97 & 2,33 & 26,84 & 3,46 \\
& 3 & 37,65 & 4,19 & 35,75 & 2,31 \\
& 4 & 44,09 & 3,73 & 42,31 & 2,25 \\
& 5 & 48,67 & 2,88 & 47,82 & 3,63 \\
\hline Betina & 1 & 18,50 & - & 17,15 & - \\
& 2 & 26,30 & 3,92 & 26,44 & 3,50 \\
& 3 & 34,61 & 2,88 & 33,74 & 2,26 \\
& 4 & 42,68 & 3,52 & 38,45 & 2,22 \\
& 5 & 46,52 & 3,38 & 45,52 & 4,05 \\
\hline
\end{tabular}
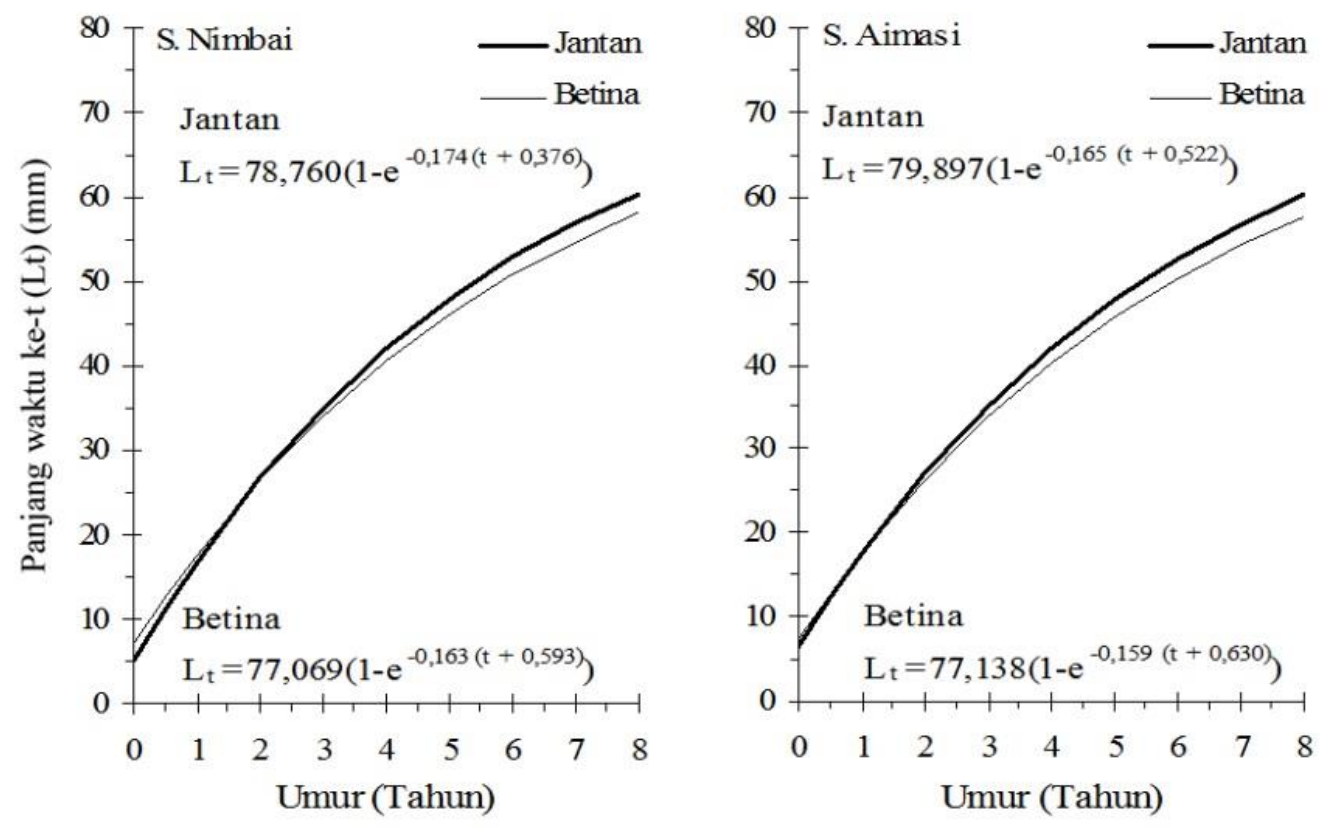

Gambar 3. Kurva pertumbuhan ikan pelangi arfak di S. Nimbai dan S. Aimasi 


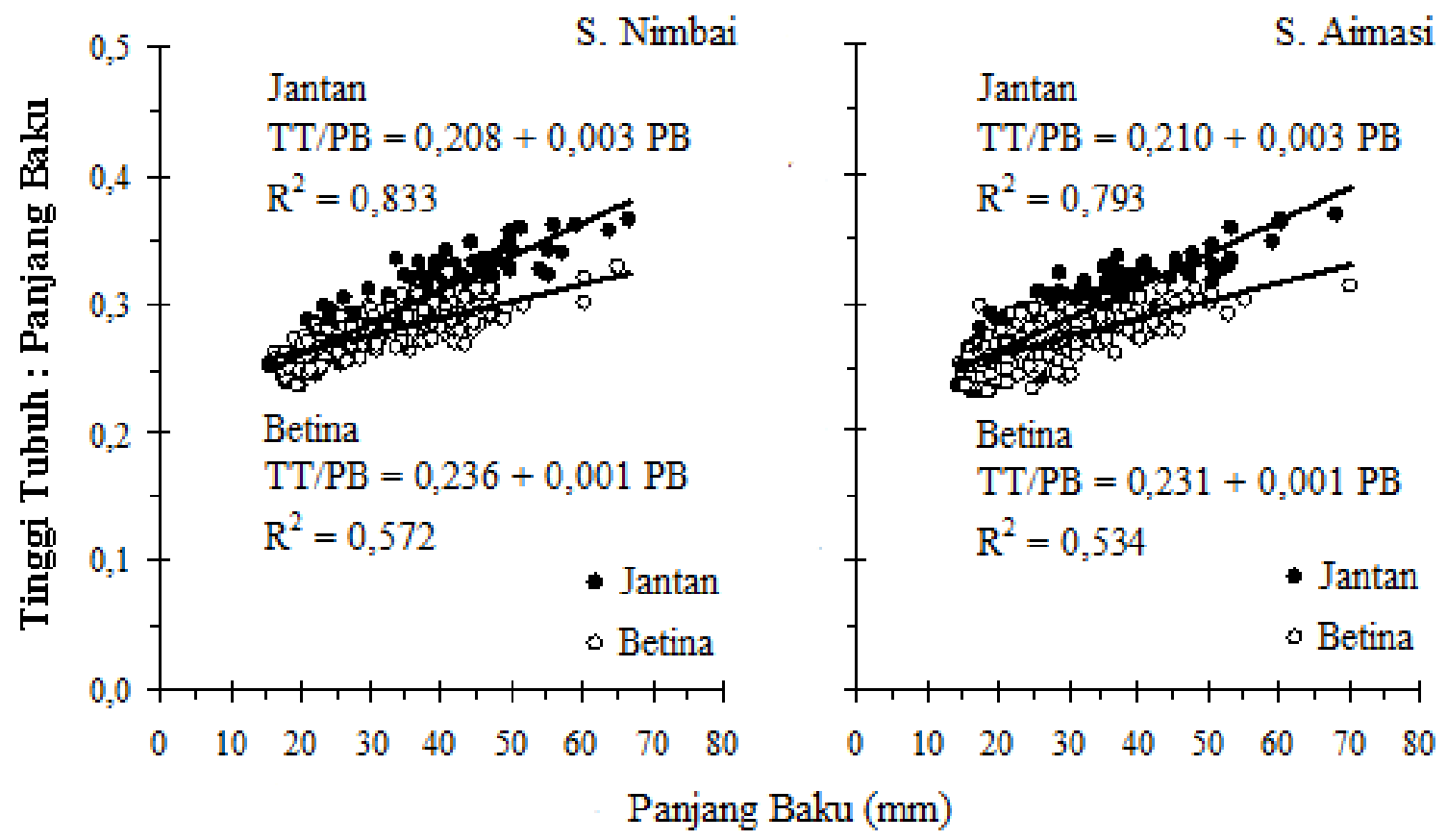

Gambar 4. Perbandingan tinggi tubuh terhadap panjang baku ikan pelangi arfak

\section{Ukuran dan Umur Kali Pertama Matang Kelamin}

Ukuran kali pertama matang kelamin yang diperoleh di kedua lokasi penelitian ditunjukkan pada Tabel 5. Individu jantan matang kelamin pada ukuran yang lebih kecil dibandingkan individu betina, dan pola yang sama ditemukan juga di beberapa sungai di Kebar (Tabel 5). Hasil ini mengindikasikan bahwa ikan jantan lebih dahulu matang kelamin dibandingkan individu betina. Individu betina memerlukan ukuran yang lebih besar dan umur yang lebih tua pada saat matang kelamin untuk mendapatkan jumlah telur (fekunditas) yang lebih tinggi (Stearns, 1992). Hubungan yang positif di antara ukuran individu betina ikan pelangi arfak dan jumlah telur juga telah dilaporkan oleh Manangkalangi et al., (2009b). Selain jumlah telur, ukuran individu betina juga memunyai hubungan yang positif dengan ukuran telur (Morita et al., 1999), sehingga individu betina memerlukan energi yang lebih banyak untuk mencapai tingkat kematangan kelamin.

Berdasarkan parameter pertumbuhan, umur ikan saat matang kelamin (Metode Spearman-Karber) berkisar di antara 1.83-2.18 tahun (jantan) dan 2.49-2.64 tahun (betina). Namun umur ikan mulai matang kelamin yang ditemukan dalam penelitian ini lebih tua jika dibandingkan dengan beberapa penelitian sebelumnya yang menunjukkan bahwa jenis ikan pelangi mulai matang gonad pada akhir tahun pertama masa hidupnya (Milton \& Arthington, 1984, Allen et al., 2000, Manangkalangi \& Pattiasina, 2005). Hal ini diduga berkaitan dengan variasi intraspesies dan interspesies.

\section{Karakteristik Dimorfisme Seksual}

Berdasarkan hasil pengamatan menunjukkan bahwa karakteristik dimorfisme seksual pada ikan pelangi arfak ditunjukkan dari karakter tinggi tubuh. Individu jantan memiliki tubuh yang lebih tinggi dibandingkan individu betina. Karakteristik ini ditunjukkan melalui nilai proporsi tinggi tubuh terhadap panjang baku yang lebih besar (Tabel 6). Hasil penelitian ini menunjukkan bahwa semakin besar ukuran panjang baku, maka proporsi tinggi tubuh terhadap panjang tubuh semakin besar (Gambar 4). Perbandingan ini relatif sama pada individu berukuran lebih kecil di antara kedua jenis kelamin. Perbedaan proporsi di antara kedua jenis kelamin mulai terjadi ketika panjang baku berukuran > $22.48 \mathrm{~mm}$ di Sungai Nimbai dan $>18.22 \mathrm{~mm}$ di Sungai Aimasi (melalui perpotongan garis regresi di antara kedua jenis kelamin) (Gambar 4). Kondisi ini terjadi ketika individu jantan mulai mendekati kondisi kali (PB 
pertama matang kelamin. Pada individu yang berukuran lebih besar, maka perbedaan proporsi ini semakin jelas di antara kedua jenis kelamin. Nilai perbandingan tinggi tubuh terhadap pandang baku pada individu jantan Melanotaenia arfakensis yang berukuran besar (PB 47-80 mm) sebesar 0.34-0.38 dan pada individu betinanya
40-53 mm) sebesar 0.28-0.34 (Allen, 1990). Demikian juga pada Melanotaenia splendida, dimorfisme seksual yang berkaitan dengan proporsi tinggi terhadap panjang tubuh nampak jelas ketika ikan mencapai ukuran panjang baku yang lebih besar (PB 37-42 mm) (Humphrey et al., (2003).

Tabel 5. Ukuran panjang baku kali pertama matang kelamin ikan pelangi arfak

\begin{tabular}{|c|c|c|c|c|}
\hline \multirow{2}{*}{ Lokasi } & \multirow{2}{*}{ Jenis kelamin } & \multicolumn{2}{|c|}{ Ukuran minimum panjang baku (mm) } & \multirow{2}{*}{ Sumber } \\
\hline & & Observasi & Metode Spearman-Karber & \\
\hline \multicolumn{4}{|c|}{ Sistem Sungai Prafi (wilayah timur persebaran) } & Penelitian ini \\
\hline \multirow{2}{*}{ Sungai Nimbai } & Jantan & 24.95 & 25.077 & \\
\hline & Betina & 27.41 & 31.578 & \\
\hline \multirow{2}{*}{ Sungai Aimasi } & Jantan & 27.23 & 28.695 & \\
\hline & Betina & 28.76 & 30.224 & \\
\hline \multicolumn{4}{|c|}{ Beberapa Sungai di Kebar (wilayah barat persebaran) } & Manangkalangi \\
\hline \multirow{2}{*}{ Sungai Api } & Jantan & 23.65 & - & \& Pattiasina \\
\hline & Betina & 27.55 & - & $(2005)$ \\
\hline \multirow{2}{*}{ Sungai Asiti } & Jantan & 24.35 & - & \\
\hline & Betina & 25.40 & - & \\
\hline \multirow{2}{*}{ Sungai Atai } & Jantan & 26.15 & - & \\
\hline & Betina & 28.75 & - & \\
\hline
\end{tabular}

Tabel 6. Panjang baku dan proporsi tinggi tubuh terhadap panjang baku pada ikan pelangi arfak

\begin{tabular}{ccccc}
\hline \multirow{2}{*}{ Lokasi } & \multirow{2}{*}{ Jenis Kelamin } & \multirow{2}{*}{ Kisaran PB } & \multicolumn{2}{c}{ Proporsi TT/PB } \\
\cline { 4 - 5 } & & & Kisaran & Rataan \pm SD \\
\hline \multirow{2}{*}{ Sungai Nimbai } & Jantan & $15.64-66.61$ & $0.24-0.36$ & $0.29 \pm 0.03$ \\
& Betina & $16.60-64.94$ & $0.24-0.33$ & $0.28 \pm 0.02$ \\
\hline \multirow{2}{*}{ Sungai Aimasi } & Jantan & $14.56-68.06$ & $0.23-0.37$ & $0.28 \pm 0.03$ \\
& Betina & $14.98-70.27$ & $0.23-0.31$ & $0.27 \pm 0.02$ \\
\hline
\end{tabular}

\section{SIMPULAN}

Individu jantan ikan pelangi arfak memiliki pola pertumbuhan alometrik negatif, sedangkan individu betina alometrik positif. Laju pertumbuhan panjang tubuh pada individu jantan lebih cepat dibandingkan individu betina. Kondisi matang kelamin individu jantan dicapai pada ukuran lebih kecil dan umur yang lebih muda dibandingkan individu betina. Karakter dimorfisme seksual terlihat pada tinggi tubuh, khususnya pada individu berukuran besar.

\section{UCAPAN TERIMA KASIH}

Penulis menyampaikan terima kasih kepada Agustinus Lebang, Benyamin Mandosir, dan Hengky Kaiway yang telah membantu mengoleksi contoh ikan di lapangan maupun penanganannya di laboratorium.

\section{DAFTAR PUSTAKA}

Allen GR. 1990. Les poissons arc-en-ciel (Melanotaeniidae) de la Péninsule de 
Vogelkop, Irian Jaya, avec description de trois nouvelles espèces. Revue française d'Aquariologe, 16(4): 101-112.

Allen GR, Hortle KG, Renyaan SJ. 2000. Freshwater fishes of the Timika Region New Guinea. PT. Freeport Indonesia. 175p. Essington TE, Kitchell JF, Walters CJ. 2001. The von Bertalanffy growth function, bioenergetics, and the consumption rates of fish. Canadian Journal of Fisheries and Aquatic Sciences, 58(11): 2129-2138.

Freitas TMS, Almeida VHC, Montag LFA, Fontoura NF. 2016. Predicting size at first sexual maturity from lenth/weight relationship: a case study with an Amazonian catfish. Neotropical Ichthyology, 14(4): e150152.

Gayanilo FC Jr, Sparre P, Pauly P. 1996. FAOICLARM stock assessment tools User's manual. FAO, Rome. 126 p.

Gonzalez-Ganadara, C., E. Perez-Diaz, L. SantosRodriguez, J.E. Arias-Gonalez, 2003. Lengthweight relationships of coral reef fishes from the Alacran Reef, Yucantan, Mexico. NAGA, ICLARM Q., 26(1): 14-16.

Humphrey C, Klumpp DW, Pearson R. 2003. Early development and growth of the eastern rainbowfish, Melanotaenia splendida splendida (Peters) I. Morphogenesis and ontogeny. Marine and Freshwater Research, 54(1): 17-25.

IUCN 2018. The IUCN Red List of Threatened Species. Version 2017-3. http://www. iucnredlist.org. [accessed on 7 May 2018].

Jonsson B, Jonsson N. 2011. Ecology of atlantic salmon and brown trout: habitat as a template for life histories. Fish and Fisheries Series 33, Springer, Dordrecht.

Kadarusman, Hubert N, Hadiaty RK, Sudarto, Paradis E, Pouyaud L. 2012. Cryptic diversity in Indo-Australian rainbowfishes revealed by DNA barcoding: implications for conservation in a biodiversity hotspot candidate. Plos ONE, 7(7): e40627.

Lambert Y, Dutil J-D. 1997. Can simple condition indices be used to monitor and quantify seasonal changes in the energy reserves of Atlantic cod (Gadus morhua)? Canadian
Journal of Fisheries and Aquatic Sciences, 54(Suppl. 1): 104-112.

Le Cren CD. 1951. The length-weight relationship and seasonal cycle in gonad weight and condition in perch, Perca fluviatilis. Journal of Animal Ecology, 20: 201-209

Lloret J, Planes S. 2003. Condition, feeding and reproductive potential of white seabream Diplodus sargus as indicators of habitat quality and the effect of reserve protection in the northwestern Mediterranean. Marine Ecology Progress Series, 248: 197-208.

Manangkalangi E, Pattiasina TF. 2005. Studi pendahuluan aspek reproduksi dan pertumbuhan ikan rainbow (melanotae niidae) di perairan tawar Distrik Kebar Kabupaten Manokwari. Jurnal Perikanan dan Kelautan, 1(2): 87-94.

Manangkalangi E, Rahardjo MF, Sjafii DS. 2009a. Habitat ontogeni ikan pelangi arfak (Melanotaenia arfakensis) di Sungai Nimbai dan Sungai Aimasi, Manokwari. Jurnal Natural, 8(1): 4-11. Manangkalangi E, Rahardjo MF, Sjafei DS, Sulistiono. 2009b. Musim pemijahan ikan pelangi arfak (Melanotaenia arfakensis Allen) di Sungai Nimbai dan Sungai Aimasi, Manokwari. Jurnal Iktiologi Indonesia, 9(1): 1-12.

Manangkalangi E, Leatemia SPO, Lefaan PT, Peday HFZ, Sembel L. 2014. Kondisi habitat ikan pelangi arfak, Melanotae nia arfakensis di Sungai Nimbai, Prafi Manokwari. Jurnal Iktiologi Indonesia, 14(1): 21-36.

Meretsky VJ, Valdez RA, Douglas ME, Brouder MJ, Gorman OT, Marsh PC. 2000. Spatiotemporal variation in length-weight relationships of endangered humpback chub: implica tions for conservation and management. Transactions of the American Fisheries Society, 129: 419-428.

Milton DA, Arthington AH. 1984. Reproductive strategy and growth of the crimson-spotted rainbowfish, Melanotaenia splendida fluviatilis 
(Castelnau) (Pisces: Melanotaeniidae) in south-eastern Queensland. Australia Journal of Marine and Freshwater Research. 35 (1):75-83.

Morita K, Yamamoto S, Takashima Y, Matsuishi T, Kanno Y, Nishimura K. 1999. Effect of maternal growth history on egg number and size in wild white-spotted charr (Salvelinus leucomaenis). Canadian Journal of Fisheries and Aquatic Sciences, 56: 15851589.

Okgerman H. 2005. Seasonal variations in the length-weight relationship and condition factor of rudd (Scardinius erythrophthalmus L.) in Sapanca Lake. International Journal of Zoological Research, 1(1): 6-10.

Plaistow SJ, Lapsley CT, Beckerman AP, Benton TG. 2004. Age and size at maturity: sex, environmental variability and developmental thresholds. Proceedings of the Royal Society of London Series B, 271: 919-924.

Polhemus DA, Englund RA, Allen GR. 2004. Freshwater biotas of New Guinea and nearby islands: analysis of endemism, richness, and threats. Bishop Museum, Honolulu, Hawaii. 62 p.
Ribeiro F, Crain PK, Moyle PB. 2004. Variation in condition factor and growth in young-of-year habitats of the Cosumnes River, California. Hydrobiologia, 527(1):77-84.

Sparre P, Venema SC, 1998. Introduction to tropical fish stock assessment. Part I: Manual. FAO Fisheries Technical Paper No. 306, Rome. 407 p.

Stearns SC. 1992. The evolution of life histories. Oxford: Oxford University Press.

Stevenson RD, Woods WA. 2006. Condition indices for conservation: new uses for evolving tools. Integrative and Comparative Biology, 46(6): 11691190.

van Poorten BT, Walters CJ. 2016. How can bioenergetics help us predict changes in fish growth patterns? Fisheries Research, 180: 23-30.

Udupa KS. 1986. Statistical method of estimating the size at first maturity in fishes. ICLARM, Metro Manila, Fishbyte. 4(2): 8-10. 